\title{
Dopamine Release and Presynaptic Dopaminergic Regulation in Guinea Pig Spinal Cord ${ }^{\dagger}$
}

\author{
Makoto KONDO, Hiroshi FUJIWARA and Chikako TANAKA* \\ Department of Pharmacology. Kobe University School of Medicine. \\ Kobe 650, Japan
}

Accepted January 24, 1986

\begin{abstract}
Using pharmacological approaches, we obtained evidence for the release of dopamine (DA) and its dopaminergic regulation in the guinea pig spinal cord. Electrical stimulation of the cord pieces increased the endogenous DA release and the efflux of $\left[{ }^{3} \mathrm{H}\right]$ dopamine $\left(\left[{ }^{3} \mathrm{H}\right] \mathrm{DA}\right)$ from tissues preloaded with $\left[{ }^{3} \mathrm{H}\right] \mathrm{DA}$. The evoked release of $\left[{ }^{3} \mathrm{H}\right] \mathrm{DA}$ was current- and frequency-dependent and was prevented by tetrodotoxin $\left(10^{-6} \mathrm{M}\right)$ or $\mathrm{Ca}^{2+}$-free medium containing EGTA $\left(10^{-4}\right.$ $M)$, while benztropine allowed a recovery of a more extensive amount of [ $\left.{ }^{3} \mathrm{H}\right] \mathrm{DA}$ in the superfusing medium by inhibiting the reuptake process. The stimulated $\left[{ }^{3} \mathrm{H}\right]$ DA release was reduced by LY-171555, but not by SKF-38393 and 8-Br-CAMP. (-) Sulpiride enhanced the stimulated endogenous DA and $\left[{ }^{3} \mathrm{H}\right] \mathrm{DA}$ release. $(-)$ Sulpiride reversed the inhibition of evoked [ $\left.{ }^{3} \mathrm{H}\right] \mathrm{DA}$ release induced by $L Y-171555$, while SKF-38393 and 8-Br-cAMP did not affect LY-171555-induced inhibition of evoked $\left[{ }^{3} \mathrm{H}\right] \mathrm{DA}$ release. These findings provide additional evidence for the neurotransmitter role of DA in the spinal cord of the guinea pig, and they strongly suggest the presence of presynaptic regulation of DA release via the dopamine receptor which is the $D_{2}$ type.
\end{abstract}

Several studies have suggested the possibility that dopamine (DA) in the spinal cord is not only a precursor of norepinephrine but can also act as an independent neurotransmitter in the separate DA neuron system (1. $2)$. The dopaminergic pathways were considered to descend from the nigral (A9) (1. $3)$, diencephalic (A11) (4-6) and hypothalamic (A13) (7) cell groups to the spinal cord. Recently, the descending spinal DA system has been shown to originate primarily in the diencephalic A11 cell group, forming a diencephal-spinal DA pathway (8). We obtained autoradiographical evidence for the localization of dopaminergic terminals in the spinal cord (9). However, the criteria for a neurotransmitter in case of the spinal cord

t This paper is part of a dissertation submitted by M.K. to Kobe University School of Medicine in fulfillment of the requirements for the degree of Doctor of Philosophy.

* To whom reprint requests should be addressed. has not been fully satisfied. In particular, there has been no evidence of a stimulus dependent release of DA from the cord.

The presynaptic dopamine receptors appear to modulate the rate of DA biosynthesis and impulse-induced DA release by a local negative feedback mechanism in the nigrostriatal $(10,11)$ and mesolimbic systems (1012), while the mesocortical (13) and tuberoinfundibular DA systems (11) appear to lack DA autoreceptor. There is, however, no information concerning autoreceptors in the spinal DA system. Here, we report the first data obtained about the release of DA from the spinal cord and its presynaptic regulation via the DA receptor.

\section{Materials and Methods}

Guinea pigs of both sexes, weighing 350$450 \mathrm{~g}$, were decapitated, and tracheotomy was performed to identify the segments. The segments $C_{1}-C_{5}$ were quickly removed by a complete laminectomy and divided into left 
and right halves by the cutting at the posterior median sulcus. Using small scissors under a dissecting microscope, the dorsal half of the gray matter was carefully removed from the white matter.

Endogenous DA release: The tissue preparations (approximately $55 \mathrm{mg}$ each) were set in the superfusion chamber. The tissue was then superfused at a constant rate of $0.2 \mathrm{ml} / \mathrm{min}$ with Krebs-Ringer bicarbonate solution oxygenated with $95 \% \quad \mathrm{O}_{2}$ and $5 \%$ $\mathrm{CO}_{2}$ and maintained at $37^{\circ} \mathrm{C}$. Krebs-Ringer bicarbonate solution had the following composition $(\mathrm{mM}): \mathrm{NaCl}, 118 ; \mathrm{KCl}, 3 ; \mathrm{MgCl}_{2}$, 1.2; $\mathrm{NaH}_{2} \mathrm{PO}_{4}, 1.2 ; \mathrm{NaHCO}_{3}, 23$; glucose, 11; pargyline, 0.1; and ascorbic acid, 0.5.

The superfusate was continuously collected into a test tube containing $0.1 \mathrm{ml}$ of $0.4 \mathrm{M}$ $\mathrm{HClO}_{4}$ and sodium metabisulphite $(2 \mathrm{mg}$ ) every $5 \mathrm{~min}$. Each superfusate was gathered respectively from 4 cord pieces of two animals. The superfusate was adjusted to $\mathrm{pH}$ 8.3 with $2 \mathrm{M}$ Tris- $\mathrm{HCl}$ buffer, $\mathrm{pH}$ 8.3, and $0.5 \mathrm{M} \mathrm{NaOH}$ solution. Endogenous DA in the superfusate was absorbed with $5 \mathrm{mg}$ of activated aluminum oxide and eluted with $20 \mu l$ of $0.1 \mathrm{M} \mathrm{HCl}$. DA in the eluates was determined using HPLC (Hitachi 655 liquid chromatograph) with an electrochemical detector (IRCA E-502) as described in our previous reports $(14,15)$.

$\left[{ }^{3} \mathrm{H}\right] \mathrm{DA}$ release: The preliminary uptake experiment was performed to determine the best conditions for the $\left[{ }^{3} \mathrm{H}\right] D A$ loading to the tissues. The dorsal half of the gray matter (approximately $5 \mathrm{mg}$ each) was preincubated for $10 \mathrm{~min}$ at $37^{\circ} \mathrm{C}$ in $2 \mathrm{ml}$ of Krebs-Ringer bicarbonate solution containing benztropine. DMI or ouabain equilibrated with $95 \% \mathrm{O}_{2}$ and $5 \% \mathrm{CO}_{2}$ and then incubated with $\left[{ }^{3} \mathrm{H}\right]-$ DA $\left(10^{-7} \mathrm{M}\right)$ for $15 \mathrm{~min}$ at $37^{\circ} \mathrm{C}$ in the same medium. After incubation, the tissues were rinsed in $10 \mathrm{ml}$ of fresh medium 3 times every $10 \mathrm{~min}$ and then dissolved by sonication in $0.5 \mathrm{ml}$ of sodium laurylsulfate (10\%). The radioactivity in the tissue was measured in a liquid scintillation spectrometer.

In the release experiments, the spinal cord pieces (approximately $5 \mathrm{mg}$ ) were loaded with the medium containing $\left[{ }^{3} \mathrm{H}\right] \mathrm{DA}\left(10^{-7}\right.$ $\mathrm{M})$ and $\mathrm{DMI}\left(5 \times 10^{-6} \mathrm{M}\right)$ for $45 \mathrm{~min}$ at $37^{\circ} \mathrm{C}$. After rinsing with fresh medium, the pre- paration was mounted in the superfusion chamber, then superfused with the medium as described above. The superfusion chamber was saturated with $95 \% \quad \mathrm{O}_{2}$ and $5 \% \quad \mathrm{CO}_{2}$ throughout the experiment. The period of equilibration before the start of the experiment was $30 \mathrm{~min}$. The superfusate was continuously collected every $5 \mathrm{~min}$, and the radioactivity determined in a liquid scintillation spectrometer. The unchanged $\left[{ }^{3} \mathrm{H}\right]$ DA in the superfusate was estimated using HPLC $(14,15)$. A half-volume $(0.5 \mathrm{ml})$ of the samples was used to separate unchanged $\left[{ }^{3} \mathrm{H}\right] \mathrm{DA}$, and the remaining parts of the samples were prepared for estimation of the total radioactivity. To the sample was added $10 \mathrm{ng}$ of labeled DA as the carrier, and DA in the samples was extracted by the alumina absorption method and identified by HPLC, as described above. The fractions containing DA were collected from the outflow of HPLC, and radioactivity in these fractions was determined by liquid scintillation spectrometer. The amounts of unchanged $\left[{ }^{3} \mathrm{H}\right] D A$ in the sample obtained before and during the stimulation period were $75 \pm 4.85$ and $76 \pm 7 \%$ of the total radioactivity, respectively. Accordingly, the total radioactivity in the superfusate was considered to represent the approximate amount of $\left[{ }^{3} \mathrm{H}\right] \mathrm{DA}$ and, therefore, will further be denoted as $\left[{ }^{3} \mathrm{H}\right] \mathrm{DA}$ release.

Electrical stimulation: The preparation was impaled with a pair of parallel platinum electrodes $(0.1 \mathrm{~mm}$ in diameter; distance, $1.5 \mathrm{~mm}$ ). Stimulation composed of monophasic pulses ( $1 \mathrm{msec}$ duration) were applied for $2 \mathrm{~min}$ at various intensities of current $(0.5-$ $3.0 \mathrm{~mA})$ and different frequencies $(1-20 \mathrm{~Hz})$.

Drug and chemicals: The following drugs were gifts: LY-171555 (Eli Lilly), (-)sulpiride (Fujisawa), SKF-38393 (Smith Kline), benztropine (Merck). The following drugs were from commercial sources: $\left[{ }^{3} \mathrm{H}\right]$ dopamine $(45.4 \mathrm{Ci} / \mathrm{mmol}$, New England Nuclear), dopamine $\mathrm{HCl}$ and pargyline $\mathrm{HCl}$ (Nakarai), desmetylimipramine (Fujisawa), tetrodotoxin (Sankyo), ouabain (Takeda) and 8-Br-cAMP (Sigma). All other chemicals were of reagent grade.

Statistical analyses: Data were analyzed by Student's $t$-test, and differences were 
accepted as significant at the 0.05 level of probability.

\section{Results}

Release of endogenous DA: The contents of NA and DA of the cervical spinal cord were $218.4 \pm 6.2 \mathrm{ng} / \mathrm{g}(\mathrm{n}=6)$ and $22.53 \pm 0.75$ $n g / g(n=6)$, respectively.

When the pieces of cervical spinal cord were superfused with Krebs-Ringer bicarbonate solution, the spontaneous release of endogenous DA reached a steady state level after 10 to $15 \mathrm{~min}$. The amount of spontaneous release of DA was $61.5 \pm 17 \mathrm{pg} / \mathrm{g}$ tissue $/ 5 \mathrm{~min}$. Electrical stimulation $(1.5 \mathrm{~mA}$ current, $10 \mathrm{~Hz}$ frequency, 1 msec pulse duration) for 2 min produced a release of endogenous DA of $242 \pm 44 \mathrm{pg} / \mathrm{g}$ tissue $/ 5 \mathrm{~min}$ (Table 1). The fractional rate constant of spontaneous and stimulated DA release was approximately 0.003 and 0.012 per min, respectively.

Release of labeled DA: When the dorsal half pieces of cervical cord gray matter were incubated with $10^{-7} \mathrm{M}$ of $\left[{ }^{3} \mathrm{H}\right] \mathrm{DA}$ at $37^{\circ} \mathrm{C}$. the accumulation of $\left[{ }^{3} \mathrm{H}\right] \mathrm{DA}$ into tissue were $0.132 \pm 0.004 \mathrm{pmoles} / \mathrm{mg}$ tissue $/ 10 \mathrm{~min}$. Ouabain $\left(10^{-4} \mathrm{M}\right)$ reduced the accumulation of $\left[{ }^{3} \mathrm{H}\right] \mathrm{DA}$ by about $22 \%$ of the control. This result indicates that the uptake system of DA is an active transport through an energy-dependent process. The accumulation of $\left[{ }^{3} \mathrm{H}\right]$ DA was suppressed to $68 \%$ of control values by benztropine $\left(10^{-6} \mathrm{M}\right)$, to $53 \%$ by $\mathrm{DMI}\left(5 \times 10^{-6} \mathrm{M}\right)$ and to $26 \%$ by benztropine plus DMI. These findings indicate that $74 \%$ of DA uptake in the spinal cord is composed of the benztropine sensitive dopaminergic and the DMI sensitive noradrenergic components. Therefore, in the following release experiments, the tissues were incubated with $10^{-7} \mathrm{M}\left[{ }^{3} \mathrm{H}\right] \mathrm{DA}$ in the presence of DMI $\left(5 \times 10^{-6} \mathrm{M}\right)$ to prevent the accumulation of $\left[{ }^{3} \mathrm{H}\right] \mathrm{DA}$ into noradrenergic nerve terminals.

The spontaneous tritium efflux assumed a fairly constant level in each experiment after $60 \mathrm{~min}$ superfusion. The fractional rate constant was about 0.002 per minute. Electrical stimulation produced an increase in the tritium efflux above the level before stimulation. The stimulated $\left[{ }^{3} \mathrm{H}\right] \mathrm{DA}$ release is dependent on the applied current (0.5$3.0 \mathrm{~mA}$ ) or frequency $(1-20 \mathrm{~Hz})$ (Fig. 1). The $\left[{ }^{3} \mathrm{H}\right] \mathrm{DA}$ release induced by stimulation of a current less than $1.5 \mathrm{~mA}$ was completely suppressed by $\operatorname{TTX}\left(10^{-6} \mathrm{M}\right)$ or $\mathrm{Ca}^{2+}$ deprivation, indicating the requirement of a rapid $\mathrm{Na}^{+}$influx and the $\mathrm{Ca}^{2+}$ influx (Fig. 1A) . Significant increases in the spontaneous and stimulated $\left[{ }^{3} \mathrm{H}\right]$ DA release were produced by adding $10^{-5} \mathrm{M}$ benztropine to the superfusion medium (Fig. 2A), by which recapture of the released $\left[{ }^{3} \mathrm{H}\right] \mathrm{DA}$ from the dopaminergic nerve terminals seems to be prevented. In the tissues preloaded with $\left[{ }^{3} \mathrm{H}\right] \mathrm{DA}$ in the medium containing both benztropine and DMI, the electrical stimulation did not produce any alteration in $\left[{ }^{3} \mathrm{H}\right]$ DA release (Fig. 2B).

Presynaptic dopaminergic regulation of DA release: When the spinal cord pieces were superfused with the medium containing $10^{-5}$

Table 1. Effect of $(-)$ sulpiride on endogenous dopamine release evoked by electrical stimulation from guinea pig spinal cord pieces

\begin{tabular}{lccccc}
\hline & Before & $\begin{array}{c}\text { (pg/g/5 min }) \\
\text { During } \\
\text { stimulation }\end{array}$ & After & Rst/Rsp & $\%$ \\
\cline { 5 - 7 } Control & $62 \pm 17$ & $242 \pm 44$ & $55 \pm 18$ & $3.56 \pm 0.21$ & 100 \\
(-) Sulpiride $\left(10^{-6} \mathrm{M}\right)$ & $70 \pm 11$ & $332 \pm 59$ & $49 \pm 13$ & $4.74 \pm 0.34^{*}$ & 146 \\
\hline
\end{tabular}

Tissues were superfused with the medium containing $(-)$ sulpiride $40 \mathrm{~min}$ before the electrical stimulation $(1.5 \mathrm{~mA}, 10 \mathrm{~Hz}, 1 \mathrm{msec}$ ) for $2 \mathrm{~min}$. Each value represents the mean $\pm \mathrm{S}$. E. of 4 experiments. Rst/ Rsp indicates the ratio of the stimulated release (Rst) to the spontaneous release (Rsp) of endogenous DA. The percent was calculated from the formula: $\frac{(A-1)}{(B-1)} \times 100$, where $A$ indicates (Rst/Rsp) of experiments involving ( - ) sulpiride and B corresponds to (Rst/Rsp) of control experiments. ${ }^{*} P<0.01$ (Student's $t$-test, significant difference from Rst/Rsp of the control). 


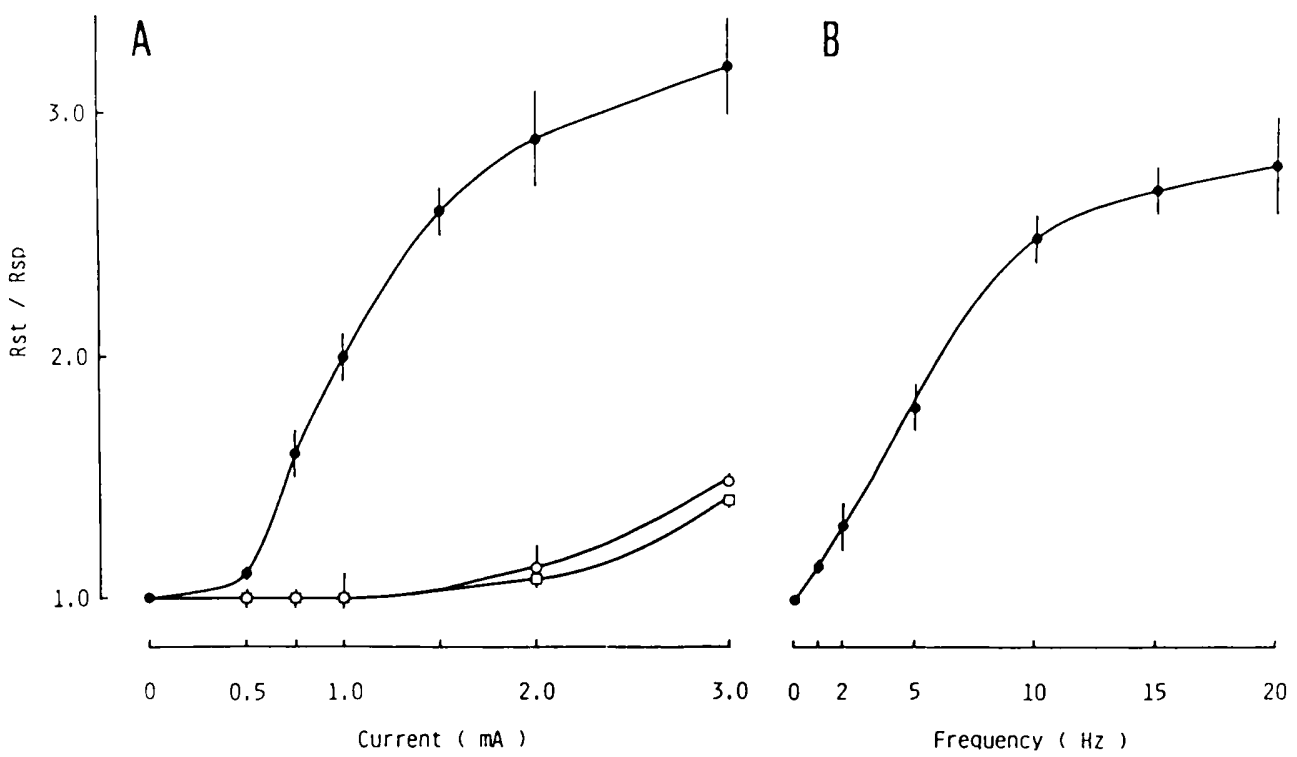

Fig. 1. The electrically stimulated release of $\left[{ }^{3} \mathrm{H}\right] \mathrm{DA}$ from the spinal cord pieces preloaded with [ $\left.{ }^{3} \mathrm{H}\right] \mathrm{DA}$ $\left(10^{-7} \mathrm{M}\right)$. The tissues were incubated in the medium containing $\left[{ }^{3} \mathrm{H}\right] \mathrm{DA}\left(10^{-7} \mathrm{M}\right)$ in the presence of DMI $\left(5 \times 10^{-6} \mathrm{M}\right)$ for $45 \mathrm{~min}$ and then superfused with the fresh medium. Each point represents the mean \pm S.E. of 6 experiments. A: Relationship between the currents of stimulation $(0.5-3.0 \mathrm{~mA})$ and the ratio of the stimulated release (Rst) to the spontaneous release (Rsp) of $\left[{ }^{3} \mathrm{H}\right] \mathrm{DA}(\mathbf{)})$. Other stimulus parameters were $10 \mathrm{~Hz}, 1 \mathrm{msec}$ for $2 \mathrm{~min}$. Effect of tetrodotoxin $(\square)$ and calcium-free medium $(\bigcirc)$ on the current dependent-stimulated $\left[{ }^{3} \mathrm{H}\right] \mathrm{DA}$ release from the spinal cord pieces preloaded with $\left[{ }^{3} \mathrm{H}\right] \mathrm{DA}$. B: Relationship between the frequencies of stimulation $(1-20 \mathrm{~Hz})$ and the ratio of the stimulated release (Rst) to spontaneous release (Rsp) of $\left[{ }^{3} \mathrm{H}\right] \mathrm{DA}$. Other stimulus parameters were $1 \mathrm{~mA}, 1 \mathrm{msec}$ for $2 \mathrm{~min}$.

M LY-171555, a $D_{2}$ receptor agonist, (16) the stimulated $\left[{ }^{3} \mathrm{H}\right]$ DA release was markedly suppressed without any changes in the spontaneous release. The stimulated $\left[{ }^{3} \mathrm{H}\right] \mathrm{DA}$ release was reduced to $63 \%$ of control values by $10^{-6} \mathrm{M}$ LY-171555. Whereas, SKF-38393 $\left(10^{-5} \mathrm{M}\right.$, a $\mathrm{D}_{1}$ agonist) and 8-Br-cAMP $\left(3 \times 10^{-3} \mathrm{M}\right)$ did not affect the evoked $\left[{ }^{3} \mathrm{H}\right]$ DA release (Table 2$),(-)$ sulpiride $\left(10^{-6}\right.$ $M)$ enhanced the stimulated $\left[{ }^{3} \mathrm{H}\right] \mathrm{DA}$ release to $150 \%$ of the control. Inhibition of stimulated $\left[{ }^{3} \mathrm{H}\right] \mathrm{DA}$ release induced by LY $-171555\left(10^{-6}\right.$ M) was also reversed by $10^{-6} \mathrm{M}(-)$ sulpiride, but not by $10^{-5} \mathrm{M} \mathrm{SKF}-38393$ or $3 \times 10^{-3} \mathrm{M}$ 8-Br-cAMP. When the preparation was superfused with the medium containing $10^{-6}$ M (-)sulpiride, endogenous DA release induced by electrical stimulation $(1.5 \mathrm{~mA}$, $10 \mathrm{~Hz}, 1 \mathrm{msec}$ ) for $2 \mathrm{~min}$ was increased to $154 \%$ of control values (Table 1 ). From these findings, DA release in the spinal cord seems to be regulated via dopamine receptors.

\section{Discussion}

The present results revealed that endogenous DA can be released from tissue stores in the isolated guinea pig spinal cord in response to electrical stimulation. Since the DA contents in the spinal cord is lower than in the dopaminergic brain area, it was difficult to detect endogenous DA released from the cord into the superfusion medium. In the present study, the electrically stimulated DA release was measured using HPLC with a sensitive electrochemical detector. Electrical stimulation (1.5 mA, $10 \mathrm{~Hz}, 1 \mathrm{msec}$ ) for $2 \mathrm{~min}$ produced a release of endogenous DA of approximate $242 \mathrm{pg} / \mathrm{g} / 5 \mathrm{~min}$. which was 4-fold spontaneous DA efflux. The properties of the stimulated DA release were analyzed using labeled DA. Labeled DA is known to be taken up by nerve terminals other than dopaminergic terminals such as noradrenergic and serotonergic terminals $(17,18)$. The 


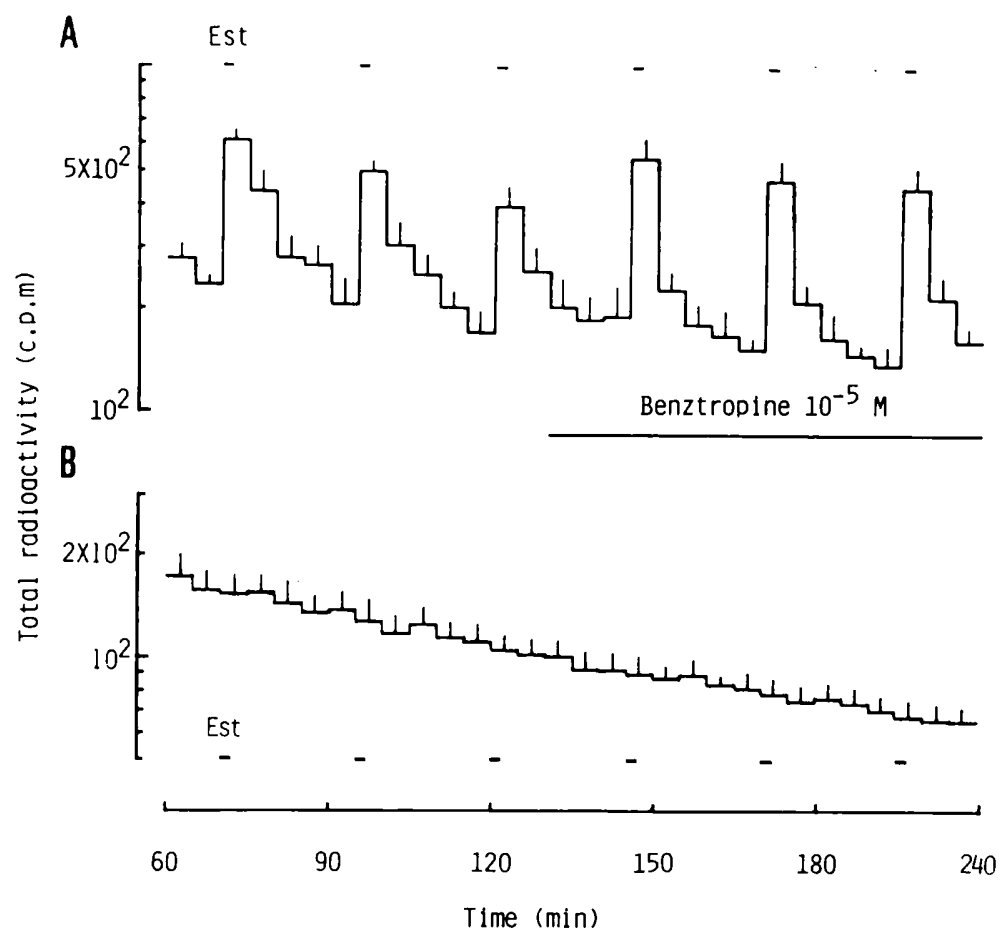

Fig. 2. A: Effect of benztropine on the electrically stimulated $\left[{ }^{3} \mathrm{H}\right] D A$ release from guinea pig spinal cord pieces preloaded with $\left[{ }^{3} \mathrm{H}\right] \mathrm{DA}$ in the presence of DMI $\left(5 \times 10^{-6} \mathrm{M}\right)$. The tissues were incubated for $15 \mathrm{~min}$ in the medium containing DMI $\left(5 \times 10^{-6} \mathrm{M}\right)$ before and during loading with $\left[{ }^{3} \mathrm{H}\right] \mathrm{DA}$ and then superfused with the same medium. The horizontal bar indicates the addition of benztropine $\left(10^{-5} \mathrm{M}\right)$ to the superfusing medium. B: Effect of the electrical stimulation on $\left[{ }^{3} \mathrm{H}\right] \mathrm{DA}$ release from the guinea pig spinal cord pieces preloaded with $\left[{ }^{3} \mathrm{H}\right] \mathrm{DA}$ in the presence of benztropine and DMI. The tissues were incubated for $15 \mathrm{~min}$ in the medium containing benztropine $\left(10^{-6} \mathrm{M}\right)$ and $\mathrm{DMI}\left(5 \times 10^{-6} \mathrm{M}\right)$ before and during loading with $\left[{ }^{3} \mathrm{H}\right] \mathrm{DA}$ and then superfused with the same medium. Est indicates electrical stimulation $(1.5 \mathrm{~mA}, 10 \mathrm{~Hz}, 1 \mathrm{msec})$ for $2 \mathrm{~min}$. Each point represents the mean \pm S.E. of 6 experiments.

Table 2. Effect of various drugs on the electrically evoked release of $\left[{ }^{3} \mathrm{H}\right] \mathrm{DA}$ from guinea pig spinal cord pieces preloaded with $\left[{ }^{3} \mathrm{H}\right] \mathrm{DA}$

\begin{tabular}{|c|c|c|}
\hline Drugs & Rst/Rsp (n) & $\%$ \\
\hline None (Control) & $2.68 \pm 0.04$ & 100 \\
\hline$L Y-171555\left(10^{-6} M\right)$ & $2.05 \pm 0.08^{*}$ & 63 \\
\hline SKF-38393 $\left(10^{-5} \mathrm{M}\right)$ & $2.69 \pm 0.05$ & 101 \\
\hline $8-\operatorname{Br}-\mathrm{CAMP}\left(3 \times 10^{-3} \mathrm{M}\right)$ & $2.54 \pm 0.09$ & 92 \\
\hline (-) Sulpiride $\left(10^{-6} \mathrm{M}\right)$ & $3.52 \pm 0.10^{*}$ & 150 \\
\hline (-) Sulpiride $\left(10^{-6} M\right)+L Y-171555\left(10^{-6} M\right)$ & $2.57 \pm 0.04$ & 94 \\
\hline SKF-38393 $\left(10^{-5} M\right)+L Y-171555\left(10^{-6} M\right)$ & $2.10 \pm 0.09^{*}(3)$ & 66 \\
\hline 8-Br-CAMP $\left(3 \times 10^{-3} M\right)+L Y-171555\left(10^{-6} M\right)$ & $2.13 \pm 0.06^{*}(3)$ & 67 \\
\hline
\end{tabular}

Tissues were superfused with the medium containing various drugs $40 \mathrm{~min}$ before the electrical stimulation (1.5 mA, $10 \mathrm{~Hz}, 1 \mathrm{msec}$ ) for $2 \mathrm{~min}$. Rst/Rsp indicates the ratio of the stimulated release (Rst) to the spontaneous release (Rsp) of $\left[{ }^{3} \mathrm{H}\right] D A .{ }^{*} P<0.05$ (Student's $t$-test, significant difference from control values). The number of experiments is given in parenthesis. The percent was expressed as indicated in Table 1. 
dopamine contents in the cervical cord is less than one-tenth of the NA and 5-HT contents $(19,20)$. Based on histochemical evidence that the spinal dopaminergic innervation is mainly confined to the dorsal horn (8), while the serotonergic and noradrenergic terminals are supplied more densely in the ventral horn rather than in the dorsal horn at the cervical level $(21) .\left[{ }^{3} \mathrm{H}\right] D A$ release in response to electrical stimulation was determined in the dorsal half pieces of the cervical cord gray matter preloaded with $\left[{ }^{3} \mathrm{H}\right] \mathrm{DA}$ and in the presence of DMI, the objective being to prevent $\left[{ }^{3} \mathrm{H}\right]$ DA uptake into the noradrenergic nerve terminals. The fractional rates of spontaneous and stimulated release of $\left[{ }^{3} \mathrm{H}\right] D A$ were in similar range to those of endogenous release, respectively. The $\left[{ }^{3} \mathrm{H}\right]$ DA release induced by stimulation of a current less than $1.5 \mathrm{~mA}$ was completely suppressed by TTX or $\mathrm{Ca}^{2+}$-deprivation, indicating the requirement of a rapid $\mathrm{Na}^{+}$ influx and the $\mathrm{Ca}^{2+}$ influx. The $\left[{ }^{3} \mathrm{H}\right] \mathrm{DA}$ release induced by low current stimulation indicates a characteristic of neurotransmitter release from presynaptic axon terminals (22. 23).

Benztropine produced increases in the spontaneous and stimulated tritium efflux. The presence of benztropine seems to prevent reuptake of the released $\left[{ }^{3} \mathrm{H}\right] \mathrm{DA}$ by the dopaminergic terminals. Furthermore, the electrical stimulation did not induce $\left[{ }^{3} \mathrm{H}\right] \mathrm{DA}$ release from the tissues preincubated with $\left[{ }^{3} \mathrm{H}\right] \mathrm{DA}$ in the presence of benztropine and DMI. These findings together with the data that the unchanged [ $\left.{ }^{3} \mathrm{H}\right] \mathrm{DA}$ accounted for $76 \%$ of the tritium suggest that the total tritium efflux by stimulus of low current reflects well the unchanged $\left[{ }^{3} \mathrm{H}\right]$ DA released from the dopaminergic nerve terminals. The DA receptor mediated modulation of the release of DA from striatal slices under in vitro conditions is by now well established (24. 25). To analyze whether the spinal DA system is regulated via presynaptic DA receptors, effects of the DA receptor agonist and antagonist on the stimulus induced $\left[{ }^{3} \mathrm{H}\right] \mathrm{DA}$ release were examined. Two types of DA receptor whose stimulation affects cellular cAMP have recently been identified. In the mammalian neostriatum, stimulation of the
DA receptor called $D_{1}$ increases formation of CAMP, whereas stimulation of the second type of $D A$ receptor called $D_{2}$ reduces cAMP formation induced by stimulation with $D_{1}$ agonist $(26,27)$. The stimulated $\left[{ }^{3} \mathrm{H}\right] \mathrm{DA}$ release in the spinal cord was reduced by LY-171555, a selective $D_{2}$ receptor agonist. This inhibitory effect was antagonized by (-)sulpiride, a selective $D_{2}$ antagonist. It thus appears that DA receptors involved in the inhibition of DA release in the spinal cord have pharmacological properties similar to presynaptic dopamine receptors of the $D_{2}$ type found in the striatum $(24,25,28)$. On the other hand, SKF-38393, a selective $D_{1}$ agonist, and $8-\mathrm{Br}-\mathrm{CAMP}$ did not have an effect on the stimulus evoked $\left[{ }^{3} \mathrm{H}\right] D A$ release, suggesting that the $D_{1}$ receptor linked to adenylate cyclase is not involved in the modulation of transmitter release from the spinal dopaminergic nerve terminals. It has been reported that drugs stimulating CAMP efflux did not affect $A C h$ release or $D_{2}$ agonist induced inhibition of $\mathrm{ACh}$ release from rat neostriatum, although the pharmacological characteristics of the DA receptors mediating inhibition of both $\mathrm{ACh}$ release and CAMP efflux appeared to be similar (29).

By analogy with the situation of ACh (27) and glutamate (29) release from the striatum, the $D_{2}$ receptor mediated inhibition of DA release was not quite affected by the $D_{1}$ agonist and 8-Br-cAMP, suggesting that the $\mathrm{D}_{2}$ receptor mediating inhibition in the spinal DA release is independent of the inhibition of CAMP generation.

Molecular characteristics of the $D_{2}$ receptor inhibiting the stimulus-induced release of DA from the spinal cord still remain to be clarified.

Acknowledgments: This work was supported by grants from the Ministry of Education, Science and Culture and the Ministry of Health and Welfare, Japan. We thank M. Ohara of Kyushu University for critical reading of the manuscript and $\mathrm{R}$. Koizumi for secretarial assistance.

\section{References}

1 Commissiong, J.W. and Neff, N.H.: Current status of dopamine in the mammalian spinal cord. Biochem. Pharmacol. 28, 1569-1573 (1979) 
2 Fleetwood-Walker, S.M. and Coote, J.H.: Contribution of noradrenaline-, dopamine- and adrenaline-containing axons to the innervation of different regions of the spinal cord of the cat. Brain Res. 206, 95-106 (1981)

3 Commissiong, J.W., Gentleman, S. and Neff, N.H.: Spina! cord dopaminergic neurons: Evidence for an uncrossed nigro spinal pathway. Neuropharmacology 18, 565-568 (1979)

4 Bjorklund, A. and Skagerberg, G.: Evidence for a major spinal cord projection from the diencephalic All dopamine cell group in the rat using transmitter-specific fluorescent retrograde tracing. Brain Res. 177, 170-175 (1979)

5 Hökfelt, T., Phillipson, $\mathrm{O}$. and Goldstei, $\mathrm{M}$.: Evidence for a dopaminergic pathway in the rat descending from the All cell group to the spinal cord. Acta Physiol. Scand. 107, 393-395 (1979)

6 Lindvall, O., Bjorklund, A. and Skagerberg, G.: Dopamine-containing neurons in the spinal cord: anatomy and some functional aspects. Ann. Neurol. 14, 255-260 (1983)

7 Blessing. W.W. and Chalmers, J.P.: Direct projection of catecholamine (presumably dopamine)-containing neurons from hypothalamus to spinal cord. Neurosci. Lett. 11, 35-40 (1979)

8 Skagerberg, G., Bjorklund, A., Lindvall, O. and Schmidt, R.H.: Origin and termination of the diencephalo-spinal dopamine system in the rat. Brain Res. Bull. 9, 237-244 (1982)

9 Kondo, M., Fujiwara, H. and Tanaka, C.: Autoradiographic evidence for dopaminergic innervation in guinea pig spinal cord. Japan. J. Pharmacol. 38, 442-444 (1985)

10 Westfall, T.C., Perkins, N.A. and Paul, C.: Role of presynaptic receptors in the synthesis and release of dopamine in the mammalian central nervous systems. Adv. Biosci. 18, 243-248 (1978)

11 Demarest, K.T. and Moore, K.E.: Comparison of dopamine synthesis regulation in the terminals of nigrostriatal, mesolimbic, tuberoinfundibular and tuberohypophysea! neurons. J. Neural Transm. 46, 263-277 (1979)

12 Nowycky, M.C. and Roth, R.H.: Dopaminergic neurons: Role of presynaptic receptors in the regulation of transmitter biosynthesis. Prog. Neuropsychopharmacol. 2, 139-158 (1978)

13 Bannon, M.J., Michaud, R.L. and Roth, R.H.: Mesocortical dopamine neurons: Lack of autoreceptors modulating dopamine synthesis. Mol. Pharmacol. 19, 270-275 (1980)

14 Fujiwara, H., Fujii, Y. and Tanaka, C.: Labeled norepinephrine uptake and release in rat globus pallidus. Brain Res. 279, 127-132 (1983)
15 Fujiwara, H., Fujii, Y., Saijoh, K. and Tanaka, C.: Evidence for the neurotransmitter role of norepinephrine in the ventral thalamic nucleus of the guinea pig: Localization, uptake and release. Brain Res. 301, 131-137 (1984)

16 Hahn, R.A. and MacDonald, B.R.: Primate cardiovascular responses mediated by dopamine receptors: Effects of $\mathrm{N}$-N-di-n-propyldopamine and $L Y-171555$. J. Pharmacol. Exp. Ther. 229, 132-138 (1984)

17 Horn, A.S., Coyle, J.T. and Snyder, S.H.: Catecholamine uptake by synaptosomes from rat brain: Structure-activity relationship of drugs with differential effects on dopamine and norepinephrine neurons. Mol. Pharmacol. 7, 66-80 (1971)

18 Berger, B. and Glowinski, J.: Dopamine uptake in serotoninergic terminals in vitro: A valuable tool for histochemical differentiation of catecholaminergic and serotoninergic terminals in rat cerebral structures. Brain Res. 147, 29-45 (1978)

19 Zivin, J.A., Reid, J.L., Saavedra, J.M. and Kopin, I.J.: Quantitative localization of biogenic amines in the spinal cord. Brain Res. 99, 293-301 (1975)

20 Commissiong, J.W., Galli, C.L. and Neff, N.H.: Differentiation of dopaminergic and noradrenergic neurons in rat spinal cord. J. Neurochem. 30, 1095-1099 (1978)

21 Carlsson, A., Falck, B., Fuxe, K. and Hiliarp, N.A.: Cellular localization of monoamines in the spinal cord. Acta Physiol. Scand. 60, 112-119 (1964)

22 Katz, R.I. and Kopin, I.J.: Release of norepinephrine- ${ }^{3} \mathrm{H}$ and serotonin- ${ }^{3} \mathrm{H}$ evoked from brain slices by electrical field stimulation-calcium dependency and the effects of lithium, ouabain and tetrodotoxin. Biochem. Pharmacol. 18, 1935-1939 (1969)

23 Katz, R.I. and Kopin, I.J.: Electrical fieldstimulated release of norepinephrine $-{ }^{3} \mathrm{H}$ from rat atrium: Effect of ions and drugs. J. Pharmacol. Exp. Ther. 169, 229-236 (1969)

24 Lehmann, J., Briley, M. and Langer, S.Z.: Characterization of dopamine autoreceptor and $\left[{ }^{3} \mathrm{H}\right]$ spiperone binding sites in vitro with classical and novel dopamine receptor agonists. Eur. J. Pharmacol. 88, 11-26 (1983)

25 Baud, P., Arbilla, S. and Langer, S.I.: Inhibition of the electrically evoked release of $\left[{ }^{3} \mathrm{H}\right]$ acetylcholine in rat striatal slices: an experimental model for drugs that enhance dopaminergic neurotransmission. J. Neurochem. 44, 331-337 (1985)

26 Stoof, J.C. and Kebabian, J.W.: Opposing roles for D-1 and D-2 dopamine receptors in efflux 
of cyclic AMP from rat neostriatum. Nature 294, 366-368 (1981)

27 Stoof, J.C. and Kebabian. J.W.: Independent in vitro regulation by the D-2 dopamine receptor of dopamine-stimulated efflux of cyclic AMP and $\mathrm{K}^{+}$-stimulated release of acetylcholine from rat neostriatum. Brain Res. 250, 263-270 (1982)

28 Kamal, L.A., Arbilla, S. and Langer, S.Z.:
Presynaptic modulation of the release of dopamine from the rabbit caudate nucleus: Differences between electrical stimulation, amphetamine and tyramine. J. Pharmacol. Exp. Ther. 216, 592-598 (1981)

29 Mitchell, P.R. and Doggett, N.S.: Modulation of striatal $\left[{ }^{3} \mathrm{H}\right]$ glutamic acid release by dopaminergic drugs. Life Sci. 26, 2073-2081 (1980) 